МИХЕЕВ Валентин Александрович - доктор исторических наук, академик РАЕН; профессор Российской академии народного хозяйства и государственной службы при Президенте РФ (119571, Россия, г. Москва, пр-кт Вернадского, 82; mikheеvva37@таil.ru)

\title{
КОМАНДА КАК СОЦИАЛЬНАЯ СТРАТА В ПОЛИТИКЕ, ГОСУДАРСТВЕННОМ УПРАВЛЕНИИ СОВРЕМЕННОЙ РОССИИ: ФОРМИРОВАНИЕ, ПРОБЛЕМА СООТВЕТСТВИЯ
}

\begin{abstract}
Аннотация. В статье поднимается проблема команд в политике и государственном управлении как социальных страт, воздействующих на политические, социально-экономические процессы, осуществляющих влияние на государство, бизнес, общество. Автор анализирует позиции ученых, политиков, исследующих формирование команд во власти, предлагает их классификацию, уделяет внимание использованию новых технологий в государственном управлении. Автор приходит к заключению об институционализации команд в политике и государственном управлении, обосновывает необходимость соответствия их деятельности современному законодательству, развитию информационного общества и национальной цифровой экономики.
\end{abstract}

Ключевые слова: команда в политике, государственном управлении, типы, стили команд, технологии управления, институционализация, цифровая экономика, информационное общество

$\mathrm{T}$ ермин «команда» в политике, государственном управлении достаточно широко распространен в политическом истеблишменте, в управлении, в повседневной практике. Это популярное выражение сложилось, во-первых, под влиянием политических условий 1990-х гг. - в соответствии с необходимостью создания крепко сплоченных общими идеями, целями групп людей во власти, государственном управлении для обеспечения устойчивости формирующейся новой политической и социально-экономической системы страны. Во-вторых, в последнее время в среде политической элиты все более отчетливо прослеживается отказ от терминов «правящий слой», «господствующий класс» и стремление позиционировать себя как команду во власти. Кстати, правовой статус властных команд, их функции и объем ответственности пока не определены ни в одном из государственных документов.

Команда в политике, государственном управлении представляет собой элитную социальную страту, способную воздействовать или оказывать давление на ход политических, социально-экономических процессов, осуществлять влияние на деятельность государства, бизнеса и общества.

Команды во власти привлекают внимание ученых, политиков в течение многих столетий - с эпохи Античности. Это позволило выработать научное определение социальной страты как совокупности людей, объединенных каким-либо одним признаком ${ }^{1}$, или интегрированной на основе единства социально значимых критериев [Сорокин 1992: 302-303].

Опыт деятельности команд в политике, государственном управлении пока не является широко распространенной темой научных исследований. Тем не менее в зарубежных исследованиях и отдельных публикациях отечественных авторов предпринимаются попытки осмысления их сущностных особенностей и значимости.

Известный американский исследователь гибкой власти Дж. Най, обращая

\footnotetext{
1 Бунимович Н.Т. и др. Словарь современных понятий и терминов. 4-е изд. дораб. и доП. М.: Республика. 2002. С. 416.
} 
внимание на существование двух типов государственной власти -командной и кооперирующей, подчеркивает, что «командная власть базируется на принципах принуждения или побуждения. Наиболее вероятными ее ресурсами являются сила, санкции, проплаты, взятки» [Най 2006: 33]. В свою очередь, кооперирующая власть, отмечает автор, базируется на привлекательности чьихлибо ценностей, культуры или же способности манипулировать таким образом, чтобы заставить других терпеть неудачу. Разница между командной и кооперирующей властью основательная. Кооперирующая власть по ресурсам и целям ассоциируется с гибкой властью поведения. В то же время командная власть обычно является жесткой [Най 2006: 34-37].

В свою очередь, исследователи Р. Мейер и Р. Майерс выделяют формирование команд во власти на основе интегрирующего и дифференцирующего стилей работы. При этом они подчеркивают, что интегрирующие лидеры при создании сплоченной команды опираются на значимость единства, а дифференцирующие - на разнообразие. Обстоятельно обосновывая достоинства и недостатки каждого из названных стилей, авторы подчеркивают, что интегрирующий стиль нередко способствует использованию нечестных методов, скрытому желанию выбирать «таких же, как мы» [Мейер, Майерс 2018: 144148]. Дифференцирующий стиль делает упор на конструктивное столкновение взглядов и постоянно направляет членов команды к конкретным действиям, с которыми все могут согласиться [Мейер, Майерс 2018: 145].

Австралийский исследователь психолог Э. Бойес обращает внимание на то, что командная работа может раздражать умных людей, сдерживать развитие человека ${ }^{1}$.

Современный отечественный опыт свидетельствует, что команды в политике, государственном управлении представляют собой разнообразные типы, стили управления и могут быть классифицированы по следующим различным основаниям:

1) статусно-организационные команды, создаваемые преимущественно в органах исполнительной власти, ассоциирующиеся в основном с правительственными структурами на федеральном, региональном и территориальном уровнях;

2) ситуативные, с учетом актуальной значимости, возникающие в условиях экономических, социальных реформ, в период разработки и реализации национальных проектов, договоров, соглашений;

3) патрон-клиентские территориальные, дружеские, семейные, формирующиеся в органах государственного управления различных ветвей власти и местного самоуправления;

4) спорадические команды, основанные на взаимных услугах, связях в целях обретения государственных должностей, статусных преференций, незаконных доходов в виде коррупционных сделок, взяток, «откатов».

По политической ориентации властные команды иногда классифицируются как демократичные, авторитарные, тоталитарные, конформистские, нонконформистские и т.д.

Типы команд по сферам деятельности можно обнаружить во всех властных структурах современной России. В этой связи подчеркнем, что формирование и деятельность команд 1-го типа осуществляются в соответствии с Конституцией РФ, существующим законодательством федерального, регионального и территориального уровней. Так, в докладе фонда «Петербургская политика» отмечается, что «победившие на осенних [2018 г.] выборах губернаторы медленно

\footnotetext{
${ }^{1}$ Бойес Э. Умным людям труднее сделать карьеру. - Ведомости. 26.11.2018.
} 
формируют свои команды, так как не проектировали всерьез свои победы» 1 , a в других случаях «даже губернаторы - кремлевские назначенцы не могут своевременно сформировать региональные команды» 2 .

Некоторые губернаторы формируют свои будущие властные команды в процессе подготовки избирательных кампаний. Так, находясь в должности губернатора Владимирской области, С.Ю. Орлова официально объявила: «Мы будем работать по-новому, и для этого необходимо, чтобы в нашу команду приходили новые люди... Дорогие мои! Я прошу вашей поддержки» ${ }^{3}$. В ответ на этот призыв представители действующей команды с чувством особого пиетета заявляют: «Я горжусь, что в команде губернатора» или «Я хочу быть в команде губернатора» 4 .

Опыт истекших 25-30 лет свидетельствует о множественности практик формирования ситуативных команд по реализации национальных и других проектов. Хорошо известно и о существовании патрон-клиентских и спорадических команд. Это подтверждается многими, в т.ч. коррупционными, делами, рассмотренными судами за последние годы.

К примеру, фигурант дела Гайзера (прежний глава Республики Коми), бывший заместитель правительства Республики Коми К. Ромаданов, получивший 7 лет строгого режима 5 , сообщает, что был участником команды как организованного сообщества, в состав которого входили высокопоставленные должностные лица республики. Суд установил, что К. Ромаданов получил взятку за назначение одного из фигурантов этого дела на должность руководителя администрации главы республики, а также за взятку продвигал второго взяткодателя на должность директора Сыктывкарского ликероводочного завода. При этом Ромаданов давал им обещания покровительства в службе и бизнесе 6 .

В нашей стране обостряется проблема приведения деятельности властных команд в соответствие с законодательством, интересами граждан, государства и бизнеса.

Сам процесс соотнесения деятельности властных команд с современными требованиями, нормами, стандартами намного сложнее, чем кажется на первый взгляд. Элитным командам необходимо так трансформировать управленческую практику, чтобы она соответствовала задачам цифровой экономики, стратегии развития информационного общества.

Центр демонстрирует необходимость соответствия деятельности органов власти целям и стратегическим задачам развития страны на период до 2024 г., на средне- и долгосрочные перспективы. Так, в майских указах Президента РФ обозначены полтора десятка важнейших направлений в различных отраслях, сферах деятельности ${ }^{7}$.

Выступая в ноябре 2018 г. на съезде Общероссийского народного фронта $(\mathrm{OH})$, В.В. Путин поставил перед ОНФ три задачи: 1) контроль за органами власти; 2) поддержка и помощь тем людям в органах власти, которые работают

${ }^{1}$ Цит. по: Мухаметшина Е. Губернаторы работают над чужими ошибками. - Ведомости. № 4690. 07.11.2018.

2 Там же.

3 Орлова С.Ю. Обращение губернатора к жителям региона. - Владимирские ведомости. 21.09.2018.

4 Земля, где хочется жить. Предвыборное издание Владимирского регионального отделения партии «Единая Россия». 27.06.2018.

5 Егоров И. Первый по делу Гайзера. - Российская газета. 09.08.2018.

6 Там же.

7 Указ Президента РФ от 07.05.2018 № 204 «О национальных целях и стратегических задачах развития Российской Федерации на период до 2024 г. Доступ: http://www.garant.ru/products/ipo/prime/ doc/71837200/ (проверено 13.01.2019). 
с душой; 3) прямое участие в выработке приоритетов развития, особенно на региональном и местном уровне 1 .

Реализация данных задач имеет особую значимость, когда в стране осуществляется заданный центром тренд выдвижения во власть нового поколения кадров, который выражается в формировании молодой когорты руководителей регионов из представителей федеральных органов власти, крупного бизнеса, корпораций с учетом специфики территорий.

В сферу государственного управления активно внедряются новейшие технологии анализа больших данных (big data), блокчейна, искусственного интеллекта, электронного документооборота ${ }^{2}$, системы комплаенса ${ }^{3}$ и др., которые предоставляют широкие возможности для решения проблем, возникающих под воздействием внутренних и внешних обстоятельств. Так, система комплаенса, применяющаяся в управленческой деятельности нашей страны с 2014 г., благодаря деятельности профессиональных команд удачно используется в финансово-банковской отрасли, электронике, медицине. Они занимаются регулированием рисков, обеспечением защиты информационных потоков, противодействием коррупции, управлением конфликтов интересов 4 .

В крупных научно-исследовательских центрах страны создаются руководящие команды, основу которых составляют авторитетные ученые, представители органов власти, бизнеса, в задачу которых входит стимулирование перехода к новому технологическому укладу. По оценкам Российской академии наук, 30\% экономики нашей страны относится к третьему технологическому укладу, 50\% - к четвертому, около 10\% - к пятому. Для сравнения, в США $20 \%$ экономики составляет четвертый, $60 \%$ - пятый и $10 \%$ - шестой технологический уклад 5 . Нас опережают не только США, но и Европейский союз, Япония, Китай, Юго-Восточная Азия 6 . То есть, речь идет о том, в средне- и долгосрочном расчете создание элитных команд в политике и управлении может помочь современной России получить ощутимую выгоду, если мы научимся достаточно умело их использовать.

Перед командами в политике и государственном управлении возникает необходимость учиться новой управленческой практике.

В этом отношении заслуживает внимания опыт работы Высшей школы государственного управления РАНХиГС при Президенте РФ по подготовке кадрового резерва, овладению знаниями о деятельности команд в сфере государственного управления, по воспитанию качеств и навыков командного взаимодействия и коммуникации ${ }^{7}$.

Проблема соответствия деятельности элитных команд современному государственному управлению тесно сопряжена с преодолением дефицита доверия органам власти. В нашей стране 1/5 граждан (20\%) выражают полное недоверие Государственной думе, Совету Федерации, правительству РФ; 19\% граждан не

1 Путин В.В. Выступление перед делегатами Общероссийского народного фронта. - Российская газета. 30.11.2018.

2 Золотова Т. Бумажная беда цифровой трансформации. - Ведомости. 30.10.2018.

3 Система комплаенса (англ. compliance - согласие, соответствие) буквально означает деятельность, представляюшую собой соответствие каким-либо внутренним или внешним требованиям, нормам. См.: https://ru.wikipedia.org/wiki/\%D0\%9A\%D0\%BE\%D0\%BC\%D0\%BF\%D0\%BB\%D0\%B0\%D0\%B5\% $\mathrm{D} 0 \% \mathrm{BD} \% \mathrm{D} 1 \% 81$

4 Греф О.Г. Объяснение своих извинений за отчет уволенного аналитика «Сбербанка СІВ». Ведомости. 08.06.2018.

5 Радзиховский Л. Бег времени. - Российская газета. 04.09.2018.

6 Там же.

${ }^{7}$ Грейханова А. Смена кадра. - Российская газета. 05.10.2018. 
доверяют областным и $23 \%$ - местным властям ${ }^{1}$. Это означает крайнюю степень напряженности, роста протестных настроений. Примечательно, что рост протестной активности населения в 2018 г. проявился в регионах, где властные команды реализовывали в основном негативную повестку, демонстрировали отсталость, усталость, неумение решать назревшие вопросы, волнующие граждан.

Одной из причин этого, как свидетельствует современная практика, является неготовность органов власти работать в условиях сложившейся в стране многопартийности, наличия оппозиции, допуска их представителей во власть.

Кроме того, элитные команды иногда из-за недостаточно ясного осознания актуальных целей и задач стратегического развития могут затуманить глубинный смысл современных масштабных преобразований. К примеру, управленческие команды, представленные в Российской трехсторонней комиссии по регулированию социально-трудовых отношений, в принятом Генеральном соглашении между общероссийскими объединениями профсоюзов, общероссийскими объединениями работодателей и Правительством РФ на период 2018-2020 гг. сформулировали и выдвинули «переход к новой модели развития страны, в основе которой лежит баланс интересов общества, государства и бизнеса» 2 . При этом хорошо известно, что «баланс интересов» может выражаться только в виртуальных сочетаниях реальных и нереальных, практически не измеряемых показателей.

Современная противоречивость, правовая и функциональная неопределенность формирования и деятельности элитных команд в политике и управлении ставит очевидный вопрос об утверждении и введении в их деятельность четкого соответствия закону, существующим стандартам, современным требованиям развития информационного общества, цифровой экономики, интеллектуальному и культурному уровню граждан. Соответственно, их создание предполагает не только сплоченную общность единомышленников, но, главное, формирование социальной страты высококвалифицированных специалистов, профессиональных управленцев, стимулирующих развитие интегрирующего и дифференцирующего стилей управления, опирающихся на значимость единства в достижении общей цели, эффективность команды, на разнообразие мировоззрения, реализацию принципа взаимодополняемости, конструктивного столкновения взглядов, на создание открытых коалиций, принимающих всех людей, готовых присоединиться и внести свой вклад в общее дело [Мейер, Майерс 2018: 138-154].

Элитные команды в политике и управлении вынуждены на ходу адаптировать государственное регулирование к новым непредсказуемо возникающим обстоятельствам, вызванных экономическими санкциями, повсеместным внедрением иностранных технологий, усложняющих решение задач обеспечения защиты интересов российских граждан, государства и общества в условиях, когда «международно-правовые механизмы, позволяющие отстаивать суверенное право государства на регулирование информационного пространства, не установлены» 3 .

Эффективность деятельности управленческих команд как социальных страт

\footnotetext{
1 Левинсон А. Иерархия недоверия. - Ведомости. 10.10.2017.

2 Генеральное соглашение между общероссийскими объединениями профсоюзов, общероссийскими объединениями работодателей и Правительством РФ на 2018-2020 годы. - Российская газета. 05.02.2018.

3 Указ Президента РФ от 09.05.2017 № 203 «О стратегии развития информационного общества в Российской Федерации на 2017-2030 годы». Доступ: http://www.garant.ru/products/ipo/prime/ doc/71570570/ (проверено 13.01.2019).
} 
в решающей мере зависит от их институционализации, что, в свою очередь, будет способствовать плодотворному поиску новых способов, эффективных механизмов государственного управления, развитию технологий координации, контроля, регулирования и проектирования.

Сложившаяся противоречивость в отношении элитных команд в государственном управлении нуждается в теоретических и прикладных научных исследованиях, способных вывести данную тему из категории пропагандистского клише, прояснить, с чем мы имеем дело. Иначе данные команды могут оказаться на обочине процесса реализации стратегических национальных приоритетов.

\section{Список литературы}

Мейер Р., Майерс Р. 2018. Виртуозное лидерство: как создать собственный репертуар лидерских стилей. М.: ИД «Дело». 392 с.

Най Дж.С. 2006. Гибкая власть: как добиться успеха в мировой политике (пер. с англ. В.И. Супруна). Новосибирск; М.: Фонд социо-прогностических исследований «Тренды». 221 с.

Сорокин П.А. 1992. Человек. Цивилизация. Общество (пер с англ.). М.: Политиздат. 544 с.

MIKHEEV Valentin Aleksandrovich, Dr.Sci. (Hist.), Academician of Russian Academy of Natural Sciences, Professor of the Russian Presidential Academy of National Economy and Public Administration (RANEPA) (82 Vernadskogo Ave, Moscow, Russia, 119571; mikheevva37@mail.ru)

\section{A TEAM AS A SOCIAL STRATUM IN POLITICS AND PUBLIC ADMINISTRATION IN MODERN RUSSIA: FORMATION, AND CORRESPONDENCE PROBLEM}

\footnotetext{
Abstract. The paper raises the issue of teams in politics and public administration as social stratum affecting political and socio-economical processes and the society, business and government themselves. The author analyzses viewpoints of academicians and politicians regarding the topic, and suggests its classification. The paper also touches on the usage of modern technologies in public administration. Finally, the paper talks about the institutionalisation of teams in politics and public administration highlighting the importance of aligning its activities to modern legislation, continuously developing information society and national digital economy.

Keywords: teams, politics, public administration, management technology, institutionalisation, digital economy, information society
} 